\title{
Bourges, 82 rue Vauvert
}

$n^{\circ} 064535$

\section{Christian Cribellier}

\section{(2) OpenEdition \\ 1 Journals}

Édition électronique

URL : http://journals.openedition.org/adlfi/13887

ISSN : 2114-0502

Éditeur

Ministère de la culture

Référence électronique

Christian Cribellier, "Bourges, 82 rue Vauvert », ADLFI. Archéologie de la France - Informations [En ligne], Centre, mis en ligne le 19 janvier 2015, consulté le 27 avril 2019. URL : http://journals.openedition.org/ adlfi/13887

Ce document a été généré automatiquement le 27 avril 2019

(c) Ministère de la Culture et de la Communication, CNRS 


\section{Bourges, 82 rue Vauvert}

n064535

\section{Christian Cribellier}

Lien Atlas (MCC) :

http://atlas.patrimoines.culture.fr/atlas/trunk/index.php?

ap_theme=DOM_2.01.02\&ap_bbox=2.324;47.026;2.473;47.130

1 Préalablement à la construction d'un projet immobilier d'une surface de $250 \mathrm{~m}^{2}$, des sondages archéologiques d'évaluation furent réalisés sur des terrains situés en périphérie ouest de l'agglomération antique de Bourges. Aucun vestige archéologique n'a été mis au jour.

INDEX

Index géographique : Centre, Cher (18), Bourges

operation Évaluation archéologique (EV) 